\title{
MDM2 SNP309 Allele
}

National Cancer Institute

\section{Source}

National Cancer Institute. MDM2 SNP309 Allele. NCI Thesaurus. Code C67099.

A single nucleotide polymorphism in the MDM2 gene associated with an earlier onset of tumors in both sporadic and hereditary cancers. 